University of Wollongong

Research Online

Faculty of Social Sciences - Papers (Archive) Faculty of Arts, Social Sciences \& Humanities

2019

Financing the Low-Carbon City: Can Local Government Leverage Public Finance to Facilitate Equitable Decarbonisation?

Paris Hadfield

University of Melbourne

Nicole T. Cook

University of Wollongong, ncook@uow.edu.au

Follow this and additional works at: https://ro.uow.edu.au/sspapers

Part of the Education Commons, and the Social and Behavioral Sciences Commons

Research Online is the open access institutional repository for the University of Wollongong. For further information contact the UOW Library: research-pubs@uow.edu.au 


\title{
Financing the Low-Carbon City: Can Local Government Leverage Public Finance to Facilitate Equitable Decarbonisation?
}

\author{
Abstract \\ As decarbonisation interventions proliferate within cities, local governments setting ambitious targets are \\ increasingly engaged in complex financial relations. Recognising the necessary cost of renewable and \\ energy efficient infrastructures, and the ever-present constraints on public funds, this paper argues that \\ finance is a critical node through which local governments advance decarbonisation in urban localities. \\ While local decarbonisation strategies have been viewed cautiously for their potential to overburden \\ individuals at the expense of more systematic and organisational change, this paper reveals a more \\ complex picture. Drawing on decarbonisation initiatives in two Melbourne municipalities-Moreland and \\ Darebin-it identifies four ways in which local governments are using public finance to achieve their \\ sustainability objectives. Local governments are brokering bulk product purchases for residents; lending \\ upfront capital for solar PV via local property taxes; purchasing energy efficient products and funding \\ innovative technology pilots; and procuring renewable energy supply through multi-stakeholder power \\ purchase agreements. By targeting lower income households and pooling resources with other \\ organisations, the paper shows that local governments can address socio-economic inequality and \\ facilitate extra-local change towards a low-carbon city. However, these incremental achievements \\ emphasise the need for co-ordination and state engagement to realise decarbonisation at a meaningful \\ scale.

\section{Disciplines} \\ Education | Social and Behavioral Sciences

\section{Publication Details} \\ Hadfield, P. \& Cook, N. (2019). Financing the Low-Carbon City: Can Local Government Leverage Public \\ Finance to Facilitate Equitable Decarbonisation? Urban Policy and Research, 37 (1), 13-29.
}




\title{
Financing the Low-Carbon City: Can Local Government Leverage Public Finance to Facilitate Equitable Decarbonisation?
}

\author{
Paris Hadfield ${ }^{1}$ and Nicole Cook $^{2}$ \\ ${ }^{1}$ Faculty of Architecture Building and Planning, University of Melbourne, Melbourne, Australia \\ ${ }^{2}$ School of Geography and Sustainable Communities, University of Wollongong, Wollongong, Australia
}

This is an Accepted Manuscript of an article published by Taylor \& Francis in Urban Policy and Research on 24 January 2018, available online:

http://www.tandfonline.com/10.1080/08111146.2017.1421532.

As decarbonisation interventions proliferate within cities, local governments setting ambitious targets are increasingly engaged in complex financial relations.

Recognising the necessary cost of renewable and energy efficient infrastructures, and the ever-present constraints on public funds, this paper argues that finance is a critical node through which local governments advance decarbonisation in urban localities. While local decarbonisation strategies have been viewed cautiously for their potential to over-burden individuals at the expense of more systematic and organisational change, this paper reveals a more complex picture. Drawing on decarbonisation initiatives in two Melbourne municipalities - Moreland and Darebin - it identifies four ways in which local governments are using public finance to achieve their sustainability objectives. Local governments are brokering bulk product purchases for residents; lending upfront capital for solar PV via local property taxes; purchasing energy efficient products and funding innovative technology pilots; and procuring renewable energy supply through multi-stakeholder power purchase agreements. By targeting lower income households and pooling resources with other organisations, the paper shows that local governments can address socioeconomic inequality and facilitate extra-local change towards a low-carbon city. However, these incremental achievements emphasise the need for co-ordination and state engagement to realise decarbonisation at a meaningful scale.

Keywords: finance, decarbonisation, governance, urban political ecology, cities, local government, Melbourne

Subject classification codes: 1604 (Human Geography) and 1605 (Policy and Administration) 


\section{Introduction: Following the Money in Low-Carbon Interventions}

Cities are seen as important political sites for advancing decarbonisation in response to anthropogenic climate change. Cities account for significant greenhouse gas (GHG) emission and energy consumption and urban-scale interventions to reduce GHG emissions have proliferated over the past decade, often in spite of inadequate national and international policies to establish limits on fossil fuel-intensive industries and practices (Bulkeley and Betsill 2013, McGuirk, Bulkeley and Dowling 2014a). Indeed, non-state and subnational government actors' response to the withdrawal of the United States from the Paris Agreement in 2017 is emblematic of local activism in this space (Young 2017). Diverse and experimental urban projects have emerged alongside transnational and subnational urban actor networks focused on climate change action, such as Local Governments for Sustainability (ICLEI), C40 Cities Climate Leadership Group, the Global Covenant of Mayors for Climate and Energy (2016), the Resilient Cities network, and collaborative municipal organisations such as the Victorian Greenhouse Alliances (Australia) (Broto 2017). In the Australian context, city-scale climate policy and rhetoric persists within a broader context of unfavourable national government frameworks which do little to establish limits on fossil fuel-based industries. Australian local governments amongst other actors are nonetheless mobilising to promote behaviour change, renewable energy use and energy efficient products. At the same time, there is a diversity of urban settings: some local governments do not consider sustainability within the scope of their services, while others are grappling with coal plant closures and associated job losses for local residents.

Recognising the uneven proliferation of city-scale climate change initiatives, policies and practices of carbon control are often conceptualised through relational 
lenses - urban carbon governance literature being an important example. This work conceptualises urban carbon governance as an assemblage of diverse actors engaged in provisional processes of policy change (McGuirk et al. 2014a). With roots in actor-network theory (Jacobs 2012, Latour 2005), analysis focuses on the ways in which decarbonisation interventions are processual and precarious achievements. Decarbonisation interventions manifest in situated contexts through an ongoing assembling of connections between heterogeneous actors and translocal flows of ideas, expertise and knowledge (McGuirk et al. 2014a, Rutherford and Jaglin 2015, Webb 2015). The achievement of carbon reduction hence emerges through the efforts of diverse actors that, in collaboration, take on new roles and functions in urban spaces.

This work underscores local government as a key agent in advocating for climate change action and seeking to influence carbon-conscious practices in localities, documenting the diverse and fine-grained ways in which concern for carbon control is 'stitched into place.' Earlier work describes the ways in which local authorities render climate an "object of urban governance" via GHG emissions accounting practices that attach measures of carbon to the local scale, rendering carbon governable and citizens carbon conscious (Rice 2010). Moreover, local governments are implementing behaviour change and demonstration initiatives, and enabling low-carbon and energy efficient retrofitting of urban built environments (McGuirk, Dowling and Bulkeley 2014b, Tweed 2014, Zeppel 2011). This work recognises the increasingly experimental role of local governments and the ways in which decarbonisation interventions seek to promote renewable or low-carbon energy behaviours among residents in urban contexts, through for example demonstration workshops with householders to promote more energy efficient and 
energy conscious day to day practices (Bulkeley and Broto 2013, Dodson 2014, McGuirk et al. 2015, McGuirk, Bulkeley and Dowling 2016, Rutherford 2011). However, these decarbonisation interventions are also viewed cautiously for their potential to over-burden individuals at the expense of more systematic and organisational change.

Drawing on the theoretical framework of urban political ecology (UPE), Rice (2014) argues that programs aiming to enlist individuals in low-carbon practices and technology uptake potentially draw attention away from wider infrastructures and systems underpinning urban carbon flows such as energy supply and distribution, manufacturing, and waste. In the field of UPE, urbanisation is a process that hinges on the manipulation and commodification of nature whereby "the city both facilitates and regulates global to local flows of capital and resources, people and ideas, energy and waste through the making and remaking of socio-nature" (Rice 2014, p.382). However, the process of urbanisation and the production of socio-natures are embedded in relations of power that produce uneven distributions of resources, social outcomes and risk (Heynan et al. 2006). In the context of low-carbon behaviour change initiatives, municipalities may redistribute the responsibility and cost of decarbonisation from collective to individual management (Webb 2012). Rather than cultivate a concern for carbon among corporations and institutions across energy-related sectors and scales, the individualisation of carbon mitigation may produce 'collective denial' (Cohen 2001) about the fundamental changes required to decarbonise urban consumption. Webb (2012, p. 121) has suggested carbon mitigation based on behaviour change potentially leaves markets "exempt from questions of collective responsibility, while governments' role is limited to enabling, rather than leading or directing." There are risks, too, that consumer-based 
strategies can disadvantage lower-income households who consume less carbon but may not have the financial resources to benefit from new technologies (Gabriel et al. 2016; Waitt et al. 2012). Thus, while municipal carbon governance has certainly seen localised innovations in defining the problem of climate change, urban political ecologists have questioned the capacity for local governments to facilitate more systemic, meaningful and equitable transition.

Given these criticisms, the extent to which local government can facilitate redistributive models of decarbonisation, through public finance, is not well understood. This may reflect the constraints faced by local governments with finite budgets, limited regulatory power, and geographical fragmentation to effect change (Bridge et al. 2013, Bulkeley and Betsill 2013, Cheung, Davies and Trück 2016, Hodson, Marvin and Bulkeley 2013, Jones 2012, McGuirk et al. 2014b). However, these factors also (paradoxically) incentivise local governments to act strategically in terms of their debt and investment relationships with other actors. In the United Kingdom (UK), for example, local governments have invested in municipally-owned or part-owned energy service companies (ESCos) (an 'arm's length' legal entity distinct from the local government) for local energy provision managed by the local authority, such as Woking Borough Council's Thamesway Energy Ltd (Bolton and Hannon 2016). This is distinct from largely privatised energy systems characteristic of neoliberal democracies. Elsewhere, energy supply contracts have been established through community choice aggregation (collecting customers within a municipality) where the Cincinnati region in Ohio (US), for example, negotiated a purchase agreement for $100 \%$ renewable energy supply to the locality from a regional generator (Hess 2013). Finally, tax-free municipal bonds have been issued as Property-Assessed Clean Energy (PACE) financing to support residential 
purchases of renewable technologies in Berkeley, California (US), where the local government recuperates expenditure as an additional item on property tax bills (Hess 2013). This is similar to Environmental Upgrade Agreements (EUAs) legislated in three Australian states established for energy efficiency upgrades of commercial buildings, involving a loan from a participating bank, repayments through property taxes, and electricity cost savings to supplement repayments (in some instances with tenant contributions) (McGuirk et al. 2014b; Sustainable Melbourne Fund 2017).

While these cases suggest that local governments are deploying both equity investment and debt mechanisms to take greater responsibility in low-carbon transition, we have little insight into the extent to which Australian local governments are involved in, or lead such programs; and less insight still into the capacity of municipal finance to facilitate equitable decarbonisation. Current national research has focused predominantly on categorising particular programs of carbon governance or household behaviour change rather than a focus on the financial features of these projects. At the same time, market-based mechanisms seeking to commercialise renewable energy technologies and create limits to GHG emissions tend to be documented at the national and international level. These 'top-down' approaches include feed in tariffs (FiTs) for small-scale solar energy exported to the energy grid (Hall, Foxon and Bolton 2015); renewable energy certificate trading obligations to direct investment in large-scale renewable energy generation (Bolton and Foxon 2015); legislated and voluntary carbon offset markets (Lovell and Liverman 2010); and carbon pricing (Bumpus 2015).

Recognising the financial roles that local government can play in carbon reduction and mitigation, this paper begins to bridge the gap between urban carbon governance and the new financial roles of municipalities in Australia. As Shearmur 
and Poirier (2016) argue, local government entrepreneurialism stems not simply from market motives, but from their duties to a diverse constituency and the need to manage limited department resources. Municipalities are adopting, translating and developing "everyday innovations" within municipal departments, including new products, processes and services, in order to provide sustainable municipal services to local areas (Shearmur and Poirier 2016, p. 23). While the potential for financial mechanisms to contribute to further inequalities in urban areas cannot be ignored, leveraging finance in different ways for renewable energy and energy efficient systems (including public funds, individual/household scale finance, and local businesses) will be a necessary process in urban decarbonisation (Bridge et al. 2013, Castree and Christophers 2015, Sayre 2010). In recent conceptualisations of UPE, the potential for more equitable configurations of society and nature have attracted more attention, with calls to examine the 'ever-changing interplay between people, cities, and things' (Heynen 2016). Whether and how financial innovation in local government is emerging in Australia, and the extent to which local initiatives can foster both broader scale and socially equitable decarbonisation of cities, are the key questions addressed in this study.

This paper establishes a typology of financial roles being undertaken by Australian (urban) local governments enrolled in novel financial instruments for decarbonisation. In doing so, we argue that financial relations are a critical node through which to understand urban carbon governance interventions and the ways in which local governments in particular exercise agency despite limited resources, constitutional limitations, and unsupportive state and federal policies. Through an indepth study of two LGAs within Greater Melbourne, Moreland and Darebin City Councils $^{1}$, this paper documents the changing financial relations underpinning 
innovative urban decarbonisation interventions through which local government is establishing itself as a key actor. These novel financial interventions are reconfiguring relations between urban residents, local businesses, the public sector, and the built environment. Before detailing the emerging financial roles of local governments seeking to decarbonise urban localities, the next section lays out the geographies of multilevel carbon mitigation intersecting in Melbourne. It is important to recognise that urban-scale low-carbon interventions do not operate in isolation; rather, they are entangled in relations entering and exceeding the locality, particularly through the wider electricity network. This is followed by a detailed typology of the novel financial roles undertaken by local governments in this landscape.

\section{Carbon governance in Melbourne, Australia}

\subsection{The National Context}

Urban scale decarbonisation interventions are situated within a wider state and national energy and policy context. At the national level, centralised policies are designed to regulate financial flows towards large- and small-scale renewable energy generation in the National Electricity Market $(\mathrm{NEM})^{2}$ for general energy consumption. The multi-scalar relations constituting these mechanisms for renewable energy generation in the NEM are summarised in Figure 1 below. The Large-scale Renewable Energy Target (LRET) mandates 33,000 gigawatt hours (GWh) of renewable energy supply to the grid by 2020 (Clean Energy Regulator 2017). Retailers must purchase Renewable Energy Certificates (RECs) from accredited generators annually, incentivising investment in new renewable energy infrastructure as revenue additional to wholesale electricity prices. A secondary mechanism, GreenPower, allows individuals and other entities to voluntarily purchase RECs from 
their energy retailer as GreenPower products (GreenPower 2011). GreenPower products do not replace electricity consumed from the grid (and associated electricity costs for consumers); rather, they represent a type of renewable energy offset. The Small-scale Renewable Energy Scheme (SRES) incentivises small-scale renewable energy technology uptake through subsidies at the time of purchase. Solar installation companies trade certificates which are allocated according to the estimated energy produced by the system over 15 years (Clean Energy Regulator 2017). Through this, installers can provide a discount to customers for the system. The Clean Energy Regulator, an independent statutory authority, administrates the LRET and SRES as well as other GHG emissions schemes legislated at the national level by the Federal Government.

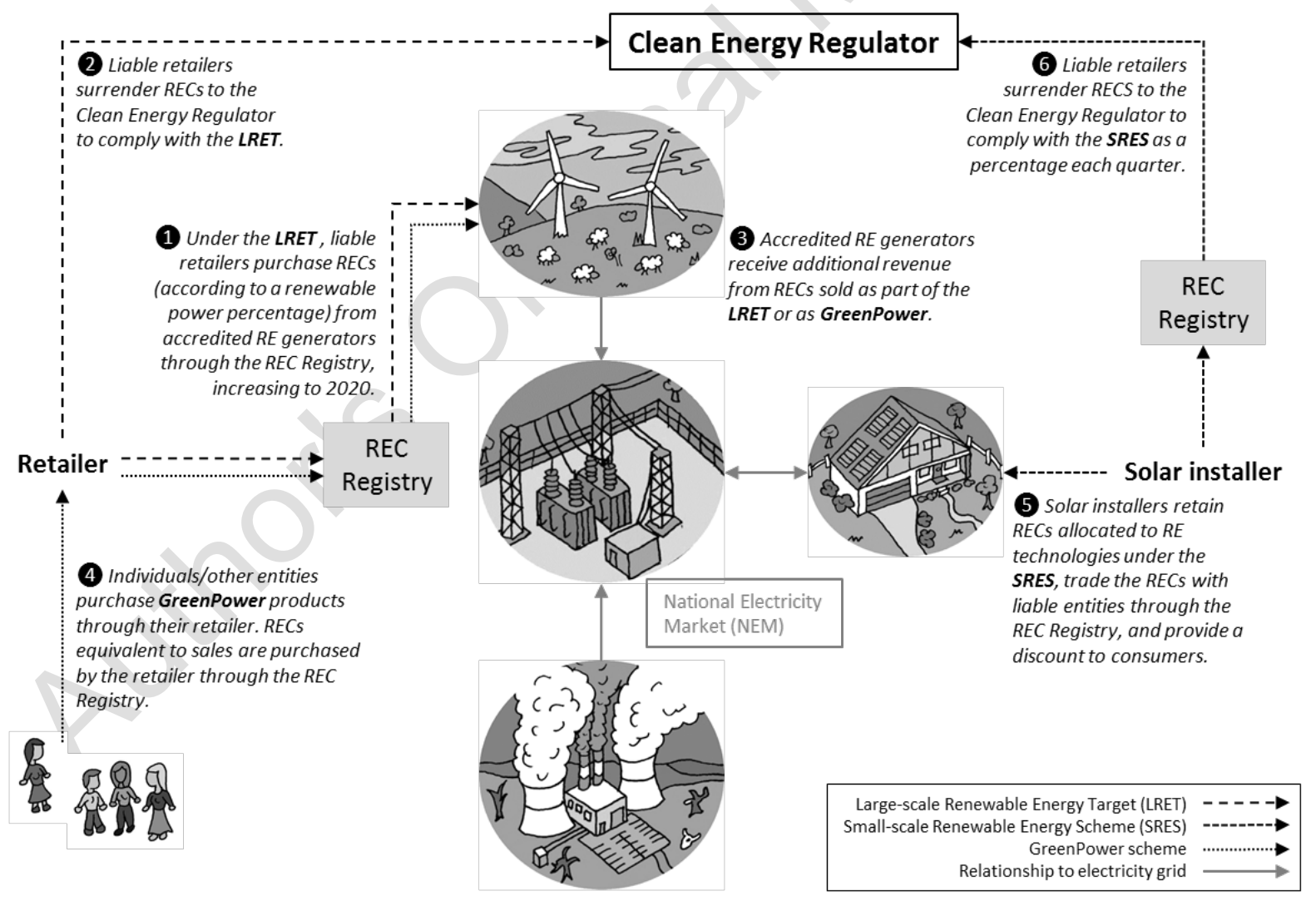

Figure 1: Geographies of renewable energy support mechanisms in the Australian NEM 
These centralised, national-level policies are necessarily drawn into urban localities in different ways. For instance, residential and commercial building energy use can be offset through GreenPower product purchases by individuals, public, and private entities through their energy retailer, while households can obtain SRES rebates on solar PV systems. They also influence the proportion of renewable energy contributing to the total pool of electricity supplying general consumption from the grid (though this remains predominantly fossil fuel-based in Victoria). Moreover, these policies coincide with state government mechanisms. State governments in Australia are the second tier of government within a three-tier system, between the Federal Government and local government. State governments are responsible for managing renewable energy feed-in tariffs (FiTs). These provide electricity bill credits for renewable energy not consumed on site and exported to the grid from small-scale systems such as household solar PV; this was increased in Victoria from 5.0c/kWh in 2016, to 11.3c/kWh on 1 July 2017 (DELWP 2017a). The Victorian Energy Efficiency Target (VEET) scheme offers rebates to energy efficient product providers according to GHG emissions savings, where consumers benefit from reduced cost products (ESC 2017). The Victorian Labor Government has also announced renewable energy targets of $25 \%$ by 2020 , and $40 \%$ by 2025 which are additional to the Federal Government's LRET scheme effective across Australia, but limited to the geographical boundaries of the state of Victoria (DELWP 2017b). The targets are to be supported by a renewable energy auction scheme, where the Victorian Government will award renewable energy generators with the lowest cost for energy generated with long-term investment contracts (DELWP 2017c). Overall, state-level mechanisms provide additional channels of financial investment for large- and small- 
scale renewable energy generation, and financial incentives for consumers of energy efficient and renewable products.

Decarbonisation in urban localities thus emerges in a complex policy landscape, compounded by political uncertainty and speculation - the LRET was reduced from 41,000 GWh by the conservative Federal Government in 2015 (Clean Energy Regulator 2017) while changes in state government leadership often signal reversals of existing policy. Nonetheless, reflective of global trends amongst local authorities towards strategic programs of carbon governance (Bulkeley and Betsill 2013), Melbourne local governments are proactively setting their own GHG emission reduction targets and sustainability objectives. The case study sites analysed in this paper, Moreland and Darebin City Councils, represent neighbouring inner metropolitan local government areas (LGAs) within Greater Melbourne selected for this study based on their ambitious environmental and climate related initiatives. ${ }^{3}$

\subsection{Case Studies and Method}

Moreland City Council has been carbon neutral in its council assets and operations under the National Carbon Offset Standard (NCOS) program since 2012. The council purchases carbon offsets through the Voluntary Offset Market and GreenPower scheme, and established a corporate emission reduction plan in 2015 with a reduction target of 30\% by 2020 based on 2011 levels (Moreland City Council 2015a). Moreland City Council established the Moreland Energy Foundation Limited (MEFL) in 2000 following the privatisation of the electricity sector in Victoria, and currently operates as a not-for-profit organisation with the overarching aim of addressing climate change locally. In collaboration, MEFL and the council produced the Zero Carbon Evolution (ZCE) Strategy for community emissions reductions 
across multiple sectors in 2014 with a 22\% reduction target from 2013 levels by 2020 (Moreland City Council 2014). Likewise, Darebin City Council's revised Climate Emergency Plan (2017) reiterates a carbon neutral emissions target within council operations and the community by 2020 (Darebin City Council 2017a, p. 20). Darebin has so far achieved a 48\% reduction in corporate emissions by 2016 based on 2007 levels through purchases of GreenPower, solar PV, and energy efficiency measures (Darebin City Council 2017a, p. 14). According to the Australian PV Institute (APVI), approximately $9.6 \%$ of dwellings have solar PV in Moreland, with an estimated total capacity of $15,536 \mathrm{~kW}$, compared with $10.8 \%$ of dwellings with solar PV in Darebin, and an estimated capacity of $15,184 \mathrm{~kW}$ (APVI 2017). These LGAs are thus comparable in the scope of their decarbonisation policies, and the level of local renewable energy uptake.

Interviews conducted in this research sought to gather and detail the multiple interventions within Moreland and Darebin respectively and illuminate how these decarbonisation targets are being achieved on the ground. In order to unpack the complex financial relations underpinning local interventions, 22 semi-structured interviews 45-60 minutes in length were conducted with representatives of 18 different organisations between May and June 2015, comprising local government councillors and officers, State Government, non-governmental organisations, municipal networks, community energy groups, a public school, an energy retailer, a solar system provider, a local sustainable design firm, and local think tanks. ${ }^{4}$ Local government initiatives were studied through the networks of actors enrolled in the governance of carbon in Moreland and Darebin (McCann and Ward 2012, McFarlane 2009, Peck and Theodore 2012), illuminating actor roles, processes, and changes in 
built forms. Throughout the paper, participants are identified by their role and organisation name.

Capturing the diverse projects and programs of urban carbon governance in Moreland and Darebin, analysis revealed that within a constrained and often toxic national policy context, local governments are moving beyond rhetoric, abstract emissions reduction targets and sustainability education by taking on new financial roles through which to achieve decarbonisation on the ground. These include brokering bulk product purchases for residents; lending upfront capital for solar PV via local property taxes; purchasing energy efficient products and funding innovative technology pilots; and procuring renewable energy supply through multi-stakeholder power purchase agreements (PPAs). While these programs are to some extent consumer-focused, they cannot simply be understood as mechanisms that transfer the costs of decarbonisation to individuals or to socio-economically marginal residents. The next section details a typology of these roles, the novel financial mechanisms employed, and the outcomes of these mechanisms in more detail.

\section{Financial mechanisms of urban carbon governance - a typology of financial} roles of local government

Moreland and Darebin City Councils emerge as experimental actors engaging in lowcarbon interventions in practical rather than merely rhetorical ways. The novel financial mechanisms outlined below enrol local actors in carbon control and reshape interactions between local governments, businesses, residents, and energy providers, as well as the sociotechnical systems of energy generation, supply, and use. Most of the mechanisms focus on energy consumption in buildings (commercial and residential); one addresses general consumption; and another addresses 
transport energy. Local government stands out as a central actor in these processes, leveraging its mandate as a community-level organisation, and its financial capacity, to directly invest in renewable and energy efficient technologies through community outreach, procurement, and demonstration pilots. While there are social and material limits to these initiatives, some focus on vulnerability and inequality among residents, and others aim to increase the capacity for renewable energy generation beyond the municipality. It is through these new relations and networks that emergent low-carbon assemblages are incrementally stitched into place. A typology of the innovative financial roles undertaken by local governments which emerge in decarbonisation interventions in Melbourne, Australia, is summarised in Table 1 and described in more detail below. 
Table 1: Financial mechanisms for local decarbonisation: local government roles and changes in urban form (summary)

\begin{tabular}{|c|c|c|c|c|}
\hline $\begin{array}{l}\text { Local government } \\
\text { roles }\end{array}$ & $\begin{array}{l}\text { Financial mechanism } \\
\text { (market/non-market) }\end{array}$ & Description & Example & Changes in urban form \\
\hline $\begin{array}{l}\text { Local government as } \\
\text { broker for resident } \\
\text { purchases }\end{array}$ & $\begin{array}{l}\text { Bulk buy solar PV } \\
\text { purchasing scheme }\end{array}$ & $\begin{array}{l}\text { Residential energy consumption: Local government } \\
\text { advertises solar PV systems to a large pool of } \\
\text { customers (residents of the LGA) for a limited time at a } \\
\text { discounted rate negotiated with the solar PV provider. }\end{array}$ & $\begin{array}{l}\text { - Resident solar PV bulk buy offers to } \\
\text { residents (Moreland and Darebin) }\end{array}$ & $\begin{array}{l}\text { Community: Urban residential rooftops are } \\
\text { remade as sites of renewable energy } \\
\text { generation and additional nodes of } \\
\text { electricity supply to the grid. }\end{array}$ \\
\hline $\begin{array}{l}\text { Local government as a } \\
\text { lender of debt finance } \\
\text { (for residential solar } \\
\text { PV) }\end{array}$ & $\begin{array}{l}\text { Low-income solar rates } \\
\text { scheme }\end{array}$ & $\begin{array}{l}\text { Residential energy consumption: Local government } \\
\text { provides the upfront capital cost of small-scale solar } \\
\text { PV systems purchased in bulk from a solar provider. } \\
\text { The systems are installed at low-income pensioner } \\
\text { households who previously signed up to the program, } \\
\text { and a special rates charge is applied to existing } \\
\text { property tax. The council recovers the debt from the } \\
\text { respective households over } 10 \text { years interest- and } \\
\text { GST-free. }\end{array}$ & $\begin{array}{l}\text { - Darebin City Council Solar Saver } \\
\text { Program ( } 292 \text { systems installed between } \\
\text { Oct and Dec 2014) }\end{array}$ & $\begin{array}{l}\text { Community: Urban (low-income) } \\
\text { residential rooftops are remade as sites of } \\
\text { renewable energy generation and } \\
\text { additional nodes of electricity supply to the } \\
\text { grid. }\end{array}$ \\
\hline \multirow[t]{3}{*}{$\begin{array}{l}\text { Local government as } \\
\text { procurer of energy } \\
\text { efficient and } \\
\text { renewable goods and } \\
\text { services }\end{array}$} & $\begin{array}{l}\text { Public investment in } \\
\text { energy efficiency } \\
\text { measures and low-carbon } \\
\text { energy generation (in situ) } \\
\text { at public buildings and } \\
\text { areas }\end{array}$ & $\begin{array}{l}\text { Commercial energy consumption: Renewable and } \\
\text { energy efficiency measures and products are } \\
\text { retrofitted to decarbonise public assets and services } \\
\text { and reduce corporate GHG emissions. }\end{array}$ & $\begin{array}{l}\text { - LED lighting upgrade of public street } \\
\text { lighting } \\
\text { - Solar PV installations on council } \\
\text { buildings } \\
\text { - Draught sealing, double glazing, and } \\
\text { insulation retrofits in public buildings } \\
\text { - Efficient HVAC retrofits in public } \\
\text { buildings } \\
\text { - Electric vehicle (EV) purchases for } \\
\text { Council fleet, and public EV charging } \\
\text { stations }\end{array}$ & $\begin{array}{l}\text { Council assets and operations: Public } \\
\text { buildings are remade as sites for } \\
\text { renewable energy generation and } \\
\text { additional nodes of energy supply to the } \\
\text { grid. } \\
\text { EV charging stations throughout the } \\
\text { municipality provide alternatives to } \\
\text { petroleum, gas and diesel fuel stations and } \\
\text { create new networks of (low-carbon) urban } \\
\text { transport infrastructure. }\end{array}$ \\
\hline & $\begin{array}{l}\text { Public investment in } \\
\text { demonstration projects }\end{array}$ & $\begin{array}{l}\text { Transport energy consumption: By providing funding } \\
\text { for a feasibility study, local government acts as a } \\
\text { partner in a technology pilot demonstration }\end{array}$ & $\begin{array}{l}\text { - Hydrogen Fuel Cell feasibility study for } \\
\text { heavy fleet vehicles (waste disposal) } \\
\text { (Moreland) }\end{array}$ & $\begin{array}{l}\text { Council assets and operations: The } \\
\text { proposed hydrogen refuelling station } \\
\text { represents a new form of (low-carbon) } \\
\text { urban transport infrastructure. }\end{array}$ \\
\hline & $\begin{array}{l}\text { Multi-stakeholder power } \\
\text { purchase agreement } \\
\text { (PPA) with regional large- } \\
\text { scale renewable generator }\end{array}$ & $\begin{array}{l}\text { General energy consumption: A consortium of } \\
\text { metropolitan stakeholders (including local } \\
\text { governments) engaged in long term energy purchase } \\
\text { contracts at an agreed rate with a single, newly built } \\
\text { regional renewable energy generator (ex situ). } \\
\text { Aggregation of multiple large energy users creates } \\
\text { certainty for the developer by ensuring future revenue. } \\
\text { The renewable energy purchased in the PPA } \\
\text { represents an offset to electricity consumed from the } \\
\text { local grid (predominantly fossil fuel-generated). }\end{array}$ & $\begin{array}{l}\text { - The Melbourne Renewable Energy } \\
\text { Project ( } 88 \mathrm{GWh} \text { ) (Moreland City Council } \\
\text { involved) }\end{array}$ & $\begin{array}{l}\text { Council assets and operations: This } \\
\text { intervention does not reconfigure the } \\
\text { urban built environment per se; rather, it } \\
\text { affects change in the composition of } \\
\text { regional electricity generation } \\
\text { infrastructure supplying the urban grid, } \\
\text { displacing a portion of fossil fuel-based } \\
\text { electricity supply. }\end{array}$ \\
\hline
\end{tabular}




\subsection{Local government as a broker for residential solar PV purchases}

Bulk buy schemes are a common means through which entities attract customers and where consumers can purchase a product at a discount. This mechanism is being employed by local government which, as a community-level body, can advertise solar PV to a large pool of potential customers (local residents) and thus negotiate with a solar provider to broker a discounted price. Darebin City Council offered a solar bulk buy rate for residents resulting in 110 household installations through 2014-15 (Darebin City Council 2015). Likewise, Moreland City Council offers solar bulk buy rates to residents and local businesses as part of its community carbon reduction strategy Zero Carbon Evolution, conducted by the social enterprise arm of MEFL, Positive Charge. The promotion to Moreland residents ran from October 2014 to June 2015 and resulted in 180 household solar PV installations with approximately AUD $\$ 750,000$ invested by residents (MEFL 2015). Ongoing solar bulk buy offers through Positive Charge also include available government subsidies, such as the Victorian Energy Efficiency Target (VEET) and the SRES (see above). By April 2016, the bulk buy scheme resulted in 1 megawatt of additional solar capacity in Moreland (Moreland City Council 2016).

This strategy illustrates local government agency in mobilising local homeowners to engage in renewable energy technology while achieving local benefit in reduced upfront costs. Moreland and Darebin City Councils actively leverage their position and reach within their respective LGAs to establish and promote small-scale solar PV bulk buy programs. The local governments seek to generate interest in solar PV amongst their constituency, thus facilitating private sector access to a large customer base. At the same time, through this collaboration, local government acts 
as a financial broker between residents and solar providers in order to reduce upfront costs of the technology and hence improve local access to renewable products. Through this, residents are engaged as investors in and managers of local renewable energy production, often identified as 'prosumers' (Rutherford and Coutard 2014) with the (intended) benefit of reduced household electricity costs over the long term. This role is central to local government community emissions reduction strategy as an indirect means for local government to reconfigure local energy systems, given their limited capacity to regulate transport and other private energy consumption. For example, while Australian local governments are responsible for maintaining local roads and footpaths, the Victorian state government is responsible for all other major transport and road development. As such, the provision of household-scale solar PV systems enabled by local governments - which co-locate electricity generation and consumption in situ - mark a socio-spatial shift towards distributed and localised ownership of energy network infrastructure (Bridge et al. 2013). Bulk buy schemes thus represent a dual logic of cultivating citizen concern for carbon (McGuirk et al. 2014a, Rice 2010) and incentivising local renewable energy use through finance. While bulk-buy schemes illuminate the ways that local governments can use financial incentives to reduce the costs to individuals of renewable energy technologies, the reconfiguration of household energy use is still circumscribed by the boundaries of private home-ownership and therefore, by housing wealth and socio-economic status. As of October 2017 for instance, the price of a 3kW solar photovoltaic (PV) system is typically around $\$ 4,700$ (including the SRES Federal rebate of $\$ 1,800$ ) (Peacock Media Group 2017); with an additional bulk-buy discount around 10-15\% (Environmental Strategy Coordinator, Darebin City Council), the purchase remains a significant financial outlay for lower-income households. Such 
programs, while reducing the costs of renewable energy to some individuals, also embed renewable energy unevenly within the municipality. It is in this context that Darebin's Solar Saver Program, detailed next, offers an alternative model with both social and economic benefits for residents with limited financial agency.

\subsection{Local government as a lender of debt finance for residential solar PV uptake}

Darebin City Council's Solar Saver program is a local government initiative seeking to increase small-scale solar PV uptake within the municipality. It also has the explicit aim of addressing exposure to high electricity costs and vulnerability to hot and cold periods among pensioner households in the community. It is important to note that pensioner households rely on modest government benefits as their main source of income in retirement and are considered low-income households. Even though they may be asset-rich as home-owners, they tend to be cash-poor, over 65 years of age and have greater health risk factors than younger age cohorts. The scheme offered pensioner households the opportunity to have solar PV installed at no upfront cost, which would instead be repaid over 10 years via a special charge attached to their quarterly rate or property tax bill, similar to the repayment process for PACE financing in the US noted above (Hess 2013). Out of a total of approximately 11,300 rate-paying pensioner households in the municipality (i.e. home-owners), 292 households voluntarily took up the first offer. The solar PV systems averaged $1.87 \mathrm{~kW}$ in size and were installed in 2014 at a cost of approximately AUD\$850,000 to the council (Environmental Strategy Coordinator, Darebin City Council; Mayor, Darebin City Council). Council charged no interest on the loans due to the target low-income demographic, effectively subsidising the installations by $3 \%$ of AUD $\$ 85,000$ per year 
that it would otherwise receive if the funds remained in the bank. Based on consumption modelling, the households involved will save approximately AUD $\$ 400$ on their annual electricity costs, while repaying approximately AUD $\$ 300$ per year to the council. The scheme thus results in an estimated AUD\$100 annual net profit over the term of the loan, after which time use of the solar PV is 'free' (Environmental Strategy Coordinator, Darebin City Council). Estimated reductions in electricity bills reflect pensioner household energy profiles due to their higher daytime energy use (corresponding with solar electricity output) compared with other resident segments. Darebin City Council committed a further AUD\$1 million to a second round of the program in 2015/16 (Darebin City Council 2016).

This initiative illustrates the innovative ways in which local government can leverage its financial assets in order to achieve emissions reductions within the locality, while also taking into account the distribution of access to renewable energy. The local government's role as a lender of debt finance for residential solar PV uptake represents local government capacity to intervene in market processes to secure benefits (namely reduced exposure to electricity bill costs) for residents otherwise lacking the financial means to access savings through renewable energy. The local government is leveraging its unique position at the community interface by mediating relations between residents and technology providers and thus remaking low-income owner-occupied household rooftops as nodes of local renewable energy generation in the achievement of decarbonisation. 


\subsection{Local government as a procurer of energy efficient and renewable goods and services}

\subsubsection{Public investment in energy efficiency measures and renewable energy generation for council assets}

Corporate-related energy efficiencies have been a key target for local governments, set out by Moreland and Darebin City Councils in their respective corporate emissions reduction strategies. Often these measures are deemed "low-hanging fruit" (Climate Change Technical Officer, Moreland City Council; ESD Consultant, Moreland City Council) in terms of the ease with which councils can intervene at reasonable cost, and which in turn achieve significant utility cost savings due to reduced energy consumption. Darebin City Council, for example, has conducted energy efficient retrofits at local aquatic centres (including insulation, energy efficient products and onsite gas co-generation) with the help of a Federal Government Grant, expected to save 2,000 tonnes GHG pa and AUD $\$ 100,000$ in operational costs (Darebin City Council 2017b). Similarly, Moreland City Council has undertaken HVAC upgrades of civic centres and libraries, accompanied by indoor thermal comfort policies (Climate Change Technical Officer, Moreland City Council) and negotiated with the electricity network provider Citipower to conduct efficient lighting upgrades along minor roads. Both local governments have invested in on-site renewable energy generation for council and other public buildings, including a 100kW solar PV system on Moreland City Council's Civic Centre (generating 30\% of the building's total energy use (Moreland City Council 2017)) and a total of 150kW of solar PV capacity installed by Darebin City Council in 2015 (Darebin City Council 2015, p. 84).

Moreland City Council have further committed to purchasing two electric vehicles (EVs) per year to replace existing council vehicles, as well as installing four public EV charging stations (Moreland City Council 2015b). This measure in 
particular is viewed as council's "responsibility to step up on behalf of the community to stimulate interest" in these technologies (Climate Change Technical Officer, Moreland City Council). Likewise, Darebin City Council plans to invest in public EV charging stations beginning the end of 2017, as well as conducting a review of the council fleet policy to increase hybrid and electric vehicle use (Darebin City Council 2017a). In addition to these procurement strategies, Moreland City Council has collaborated with low-carbon technology developers, alongside City of Sydney and City of Melbourne, by providing funds for the development of hydrogen fuel cells for heavy waste disposal vehicles (Climate Change Technical Officer, Moreland City Council).

Overall, these measures ultimately focus on demand management, where buildings with high energy consumption profiles are a particular focus for local government interventions; 'low hanging fruit' represents a high value for local government investment as a means of securing GHG emissions reductions quickly, while securing immediate cost savings from energy consumption expenditure. At the same time, both local governments recognise their role beyond end-user by actively investing in low-carbon technology development and public low-carbon transport infrastructures. These measures are also being implemented with the recognition that there are different types of carbon (see Bumpus 2011), with participants noting the difficulty in determining actions to reduce local transport emissions (Project Manager of ZCE Strategy, MEFL), and the complexity of embodied emissions in other products procured by the council that draw on non-local resources and manufacturing processes (ESD Consultant, Moreland City Council). Nonetheless, these strategies make little demand on the private sector or renewable energy access more broadly (Rice 2014). Working with other local governments and private entities to pool 
investment, the next example outlines an initiative driving larger-scale investment in renewable energy generation.

3.3.2. Multi-stakeholder power purchase agreement (PPA) with regional largescale renewable generator

Moreland City Council is one of four local governments to join a consortium of Melbourne stakeholders to establish a power purchase agreement (PPA) with a regional large-scale renewable energy generator. The PPA mechanism allows consumers to enter into a long-term contract which sets out an agreed cost per kWh for electricity generated with the provider. Led by the City of Melbourne, the Melbourne Renewable Energy Project (MREP) launched a tender process in April 2016 for 88 GWh of renewable energy over a 10 year term from a new ("shovel ready") generator (City of Melbourne 2017). ${ }^{3}$ As shown in Figure 2, the project comprises individual contracts between each consortium member and the generator via an energy retailer (PPAs), and effectively consolidates a pool of funds provided by each stakeholder. The energy to be generated and purchased over the term of the agreement will feed into the overall energy supply to the regional grid (ex-situ), while offsetting small, large and unmetered (e.g. street lighting) energy consumption.

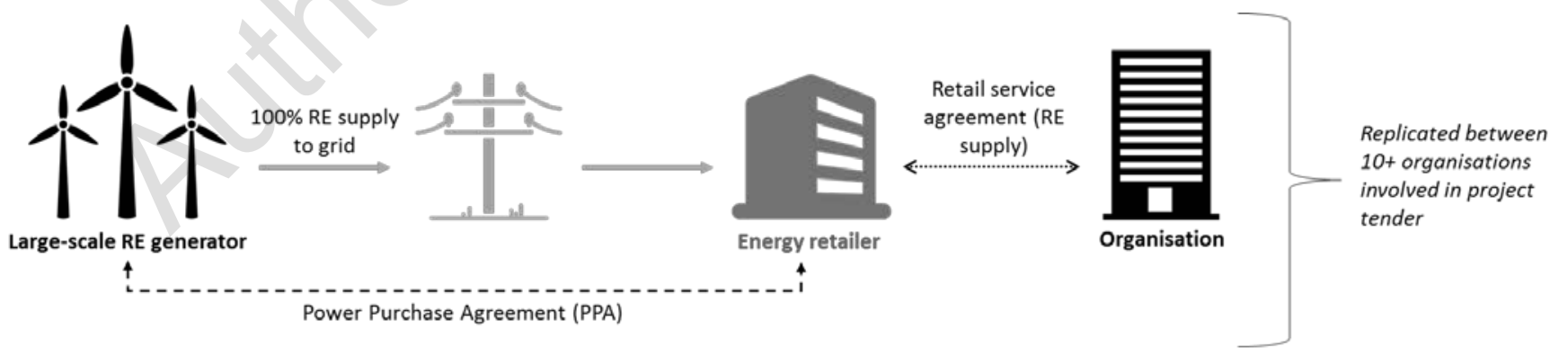

Figure 2: Melbourne Renewable Energy Project (MREP) PPA model 
This model is unique in Australia and positions local governments - rather than utilities - as influential actors in the provision of finance for large-scale renewable energy infrastructure through the procurement process. This mechanism works outside the existing national LRET (see above) as energy generated will be additional to legislated requirements for renewable energy supply. The PPA mitigates risk related to bank finance required for large-scale renewable energy development by ensuring future long-term revenue. Moreover, replicability is cited as a key motivation for the model in order to scale up renewable energy supply, reduce costs for generation, demonstrate 'bankability', and create new procurement pathways (City of Melbourne 2016). This intervention does not reconfigure the urban built environment per se; rather, it affects change in the composition of regional electricity generation infrastructure supplying the urban grid, displacing a portion of fossil fuelbased electricity supply. The project represents both an innovative financial mechanism leveraging the purchasing power of multiple local actors - within which local government is a central investor and collaborative mediator - and a novel mode of engagement with the electricity network beyond the municipality.

As shown above, local governments are increasingly engaging in novel financial arrangements in order to achieve their decarbonisation objectives. At the same time, the research illuminated the equally significant role of third party entities in the realisation of these decarbonisation interventions. Organisations such as the Northern Alliance for Greenhouse Action (NAGA) as well as other bodies including the Municipal Association of Victoria (MAV) and Local Governments for Sustainability (ICLEI) provide opportunities for information exchange and capacity building for its members. Events such as MEFL's annual Spark Conference similarly facilitate such 
exchange between local and regional stakeholders spanning multiple government levels, peak bodies, private product and service providers, community groups and individuals, think tanks, and universities. These events demonstrate how connections and the communication of ideas between diverse local and regional actors are being actively made and sustained in cities, and the significant role of organisations such as MEFL in drawing these particular actors together in space.

\section{The limitations of local government (financial) agency and urban carbon control}

Despite the innovative ways in which local governments are extending their role in community services provision to decarbonise urban spaces through financing, local governments remain inhibited by inadequate national-level policy measures to establish limits on GHG emissions and the extent to which carbon is embedded in the sociomaterial relations constituting the city. The following reports on participant reflections on the limits of the programs outlined above.

A distinct absence of unilateral agreement on climate change policy at the State and Federal Government levels has created an unstable and inconsistent political environment, a point recognised in recent studies (McGuirk et al. 2015; Bumpus 2015) and frequently made by participants. Limited and irregular grant funding from multiple levels of government for local decarbonisation projects compounds the challenge of managing a finite operations budget, where grant funding is often relied upon. Indeed, councillors and residents have varying priorities, often limited to the traditional view of local government being responsible for "roads, rates, and rubbish" which challenges local government's mandate to address sustainability (Greens Councillor, Moreland City Council; ESD Consultant, Moreland 
City Council; Mayor, Darebin City Council). Further concerns were raised in relation to the Victorian Government's rate capping legislation, limiting council's capacity to generate revenue for future projects (Greens Councillor, Moreland City Council; Mayor, Darebin City Council). These internal and external financial constraints limit the scale achievable for the rollout of local decarbonisation projects. As a result, local urban projects are characterised as slow moving and failing to reach the mainstream (Project Manager of ZCE Strategy, MEFL). Scaling up local initiatives thus remains difficult and reliant on external capital.

At the same time, decarbonisation in urban localities is constrained by the extent to which carbon is embedded in existing built forms. Mitigation of carbonintensive practices in the urban context is expensive in the absence of centralised government regulation of fossil fuel-based industries (this is indicative of the political inconsistencies noted above, where Australia's attempt to establish an Emissions Trading Scheme (ETS) was "proposed, shelved, revived, legislated, and repealed in the space of six years" (Pearse 2016, p. 1079)). Insights from urban political ecology underscore these limits as "urban interventions into climate change do little to disrupt or restructure the ways in which carbon flows into or out of cities" (Rice 2014, p. 381). The acknowledgement made by one officer that Moreland City Council's community emission reduction target of $22 \%$ by 2020 based on 2013 levels is "very much on the edge of what we think is absolute best case scenario" (Project Manager of ZCE Strategy, MEFL) alludes to the ongoing challenges of identifying and displacing carbon locally, and the disconnect between ambitious targets and their implementation. In some instances, local governments face active resistance, largely from the conservative companies managing existing electricity network infrastructures. This is attributed to a perception of decentralised renewable energy 
generation as an unpredictable connection to their network (Executive Officer, NAGA; Director of Major Projects, MEFL). While MEFL has identified opportunities to build relationships with distribution companies in relation to solar PV in industrial areas where the grid has reached capacity, these negotiations are ongoing (Director of Major Projects, MEFL; Project Manager of ZCE Strategy, MEFL).

These conditions act to protect and reinforce fossil fuel path dependency and exemplify the spatial lock-in of carbon in existing electricity systems and the wider built environment (Bridge et al., 2013). The innovative financial mechanisms in which these Melbourne local governments are enrolled are resulting in decarbonisation interventions that are distinctly limited to particular spaces in the city, namely owneroccupied households and publicly-owned buildings. It hence remains unclear whether and how local governments have the capacity to extend these new financial roles to achieve further emissions reductions beyond these spheres.

\section{Conclusions}

This paper begins to conceptualise decarbonisation as a process connecting public and private finance, municipal governance and energy-related infrastructure development. It has illustrated the importance of understanding how changing financial relations contribute to urban carbon governance interventions and, critically, the ways in which these are being leveraged by Australian local governments to achieve decarbonisation objectives in the city. This study offers a typology of the innovative financial roles being undertaken by two municipal governments in Melbourne despite limited resources, constitutional limitations, and unsupportive national policies. Enrolling in these novel mechanisms, Moreland and Darebin City Councils are leveraging finance in different ways, thus reconfiguring relations 
between residents, local businesses, the public sector, energy, and the built environment. These processes reinforce the reconfiguration of local governance around climate change mitigation as observed by McGuirk et al. (2014a, b).

In the municipalities of Moreland and Darebin, local government is a key actor which, going beyond the rhetoric of emissions reduction target setting, is directly investing in renewable and energy efficient technology retrofits and thus stitching into place emergent low-carbon assemblages comprising diverse actors and relations. The local governments are able to mobilise economies of scale at the community level, repurpose existing processes of capital exchange between residents and local government, and build upon their role as a technology end-user in experimental ways: as a broker for resident purchases of solar PV; as a lender of debt finance for residential solar PV uptake amongst low-income households; and as a procurer of and partner in energy efficient and renewable technologies, retrofitting public buildings and establishing PPAs with regional large-scale renewable energy generators.

While low-carbon initiatives have been viewed with some caution for their potential to overburden individuals rather than institutions and corporations, the paper demonstrates a more complex story. By leveraging municipal finance for household renewable energy technology, local government can address socioeconomic difference through environment and energy policy. Darebin's Solar Saver loan program illustrates local government's capacity to direct expenditure according to concerns for vulnerable residents and thus redistribute household cost benefits towards those otherwise left out of the solar PV market. While the project is limited to home-owners, targeting residents receiving a pension and who would otherwise lack the financial resources to invest in household solar shows that local government 
finance is important in facilitating more equitable decarbonisation. This further establishes municipal-scale initiatives as important sites through which the reconfiguration of social and ecological relations as envisaged in urban political ecology can occur in more equitable ways (Heynen 2016).

Indeed, while existing literature tends to equate financial interventions in carbon mitigation and climate policy with the national and international scale, this paper shows that local governments are also actively innovating in financial ways. Through financial innovation, local governments can achieve extra-local decarbonisation outcomes - a significant finding for both research and policy given that local governments continue to grapple with the prospects of achieving ambitious targets and sustainability objectives. The large-scale PPA mechanism is notable in this regard, indicating that local governments are experimenting with pathways to greater autonomy in climate-related policy (Bulkeley et al 2016). Indeed, local governments are able to gain a 'seat at the energy table' (Bridge et al. 2013) by stimulating large-scale renewable energy generation through coordinated investment across multiple local governments and urban stakeholders. Moreland City Council and others are thus identifying opportunities through public finance to scale up renewable energy production beyond the municipality. As a result, the strategies detailed in this paper cannot merely be understood as the individualisation of responsibility for carbon mitigation; rather, they suggest that local government finance plays a role in decarbonisation processes at extra-local scales.

Despite evidence of local government capacity to leverage finance to advance decarbonisation in urban localities, these emerging processes remain inhibited by stabilised configurations of fossil fuel-based energy, compounded by inadequate regulation of fossil fuel-intensive industries by the Federal Government. Thus, the 
extent to which local government can overcome these barriers and scale up decarbonisation interventions beyond the limited spheres of public buildings and owner-occupied households remains unclear. In a rapidly changing context - where low-carbon technologies are constantly being developed and proliferating at various scales, and new emissions reduction targets are being set (and modified) - further research is required to consider how urban carbon governance programs can effectively reduce GHG emissions at the scale and pace required to mitigate global climate change impacts without reinforcing urban inequalities. The mechanisms detailed here and others emerging internationally are illustrative of the significance of new financial alignments reassembling sociomaterial relations in cities from the ground up.

Acknowledgements: We would like to thank all research participants for their generosity and time. We would also like to thank two anonymous referees for their detailed feedback on this paper. Warm thanks to Christopher Cook for providing the illustrations in Figure 1.

1. 'City' in 'City Council' refers to the Local Government Area (LGA); metropolitan Melbourne comprises 31 LGAs.

2. The NEM is 'national' in name, however it only encompasses the east and south-east coasts of Queensland, New South Wales, the Australian Capital Territory, South Australia, Victoria, and Tasmania.

3. At 2016, estimated resident populations for Moreland and Darebin LGAs were 170,615 and 153,563 respectively (ID Consulting 2017). Energy data published by the Northern Alliance for Greenhouse Action (NAGA) indicates that resident electricity consumption averages $4.8 \mathrm{kWh}$ per day in both LGAs (based on data at 2013) (NAGA 2015). By sector, Darebin's industrial electricity emissions are higher than Moreland's, while both have similar levels of residential, commercial, and gas-related electricity emissions (NAGA 2015). 
4. Moreland City Council and Darebin City Council; Victorian Dept. Economic Development, Jobs, Transport and Resources; Moreland Energy Foundation Limited (MEFL) and Centre for Education and Research in Environmental Strategies (CERES); Northern Alliance for Greenhouse Action; Climate Action Moreland, Moreland Community Solar, Yarra Community Solar, Coalition for Community Energy, Community Power Agency, and The People's Solar; Brunswick Secondary College; Powershop; Energy Matters; Hip V. Hype; Beyond Zero Emissions and the Alternative Technology Association.

5. The consortium includes City of Port Phillip, City of Yarra, Next DC, Melbourne Convention Exhibition Centre, Fed Square, The University of Melbourne, NAB, Bank Australia, Citywide, RMIT University, Zoos Victoria, and Australia Post (City of Melbourne 2016).

\section{References:}

Australian PV Institute 2017, Solar Map, Australian Renewable Energy Agency, Canberra, viewed 25 April 2017, <http://pv-map.apvi.org.au/>.

Bolton, R and Foxon, TJ 2015, 'A socio-technical perspective on low carbon investment challenges-insights for UK energy policy', Environmental Innovation and Societal Transitions, 14, pp.165-181.

Bolton, R and Hannon, M 2016, 'Governing sustainability transitions through business model innovation: Towards a systems understanding', Research Policy, 45(9), pp.1731-1742.

Bridge, G, Bouzarovski, S, Bradshaw, M and Eyre, N 2013, 'Geographies of energy transition: Space, place and the low-carbon economy', Energy Policy, 53(1), pp.331340.

Broto, VC 2017, 'Urban Governance and the Politics of Climate Change', World Development, 93, pp. 1-15.

Bulkeley, H, Luque-Ayala, A, McFarlane, C, MacLeod, G 2016, 'Enhancing urban autonomy: Towards a new political project for cities', Urban Studies, pp.1-18, available as EarlyView: https://doi.org/10.1177/0042098016663836.

Bulkeley, $\mathrm{H}$ and Betsill, MM 2013,'Revisiting the urban politics of climate change', Environmental Politics, 22(1), pp.136-154. 
Bulkeley, H and Broto, VC 2013, 'Government by experiment? Global cities and the governing of climate change', Transactions of the Institute of British Geographers, 38(3), pp.361-375.

Bumpus, A 2011, 'The Matter of Carbon: Understanding the Materiality of $\mathrm{tCO}_{2} \mathrm{e}$ in Carbon Offsets', Antipode, 43(3), pp.612-638.

Bumpus, A 2015, 'Firm responses to a carbon price: corporate decision making under British Columbia's carbon tax', Climate Policy, 15(4), pp.475-493.

Castree, N and Christophers, B 2015, 'Banking Spatially on the Future: Capital Switching, Infrastructure, and the Ecological Fix', Annals of the Association of American Geographers, 105(2), pp. 378-386.

Cheung, G, Davies, PJ and Trück, S 2016, 'Financing alternative energy projects: An examination of challenges and opportunities for local government', Energy Policy, 97, pp. 354-364.

City of Melbourne 2016, Supplier Industry Briefing: The Melbourne Renewable Energy Project, City of Melbourne, Melbourne, viewed 25 April 2017, <http://www.melbourne.vic.gov.au/SiteCollectionDocuments/Industry_Briefing_Prese ntation_MREP.pdf>.

City of Melbourne 2017, Melbourne Renewable Energy Project, viewed 25 April 2017, <http://www.melbourne.vic.gov.au/business/sustainable-

business/Pages/Melbourne-Renewable-Energy-Project.aspx>.

Clean Energy Regulator 2017, Renewable Energy Target, viewed 25 April 2017, <http://www.cleanenergyregulator.gov.au/RET>.

Cohen S (2001) States of Denial: Knowing about Atrocities and Suffering.

Cambridge: Polity.

Darebin City Council 2015, City of Darebin Annual Report 2014/2015, Darebin City Council, Melbourne, viewed 25 April 2017, <http://www.darebin.vic.gov.au/ /media/EFAECC75D39A4613B5DBD4395D16BCC D.ashx>.

Darebin City Council 2016, City of Darebin Annual Report 2015/2016, Darebin City Council, Melbourne, viewed 25 April 2017, <http://www.darebin.vic.gov.au//media/cityofdarebin/Files/YourCouncil/OurPerformance/DarebinCityCouncilAnnualReport2015to2016.ashx?la=en>.

Darebin City Council 2017a, Climate Emergency Plan - August 2017, Darebin City Council, viewed 12 September 2017, < http://www.darebin.vic.gov.au/en/DarebinLiving/Caring-for-the-environment/EnergyClimate>. 
Darebin City Council 2017b, Energy and Climate, viewed 25 April 2017, $<$ http://www.darebin.vic.gov.au/Darebin-Living/Caring-for-the-

environment/EnergyClimate>.

Department Environment, Land, Water and Planning 2017a, Victorian Feed-in Tariff, viewed 25 April 2017, <http://delwp.vic.gov.au/energy/electricity/victorian-feed-intariff>.

Department Environment, Land, Water and Planning 2017b, Victoria's Renewable Energy Targets, viewed 25 April 2017,

<http://www.delwp.vic.gov.au/energy/renewable-energy/victorias-renewable-energytargets $>$.

Department Environment, Land, Water and Planning 2017c, Victorian Renewable Energy Auction Scheme: Consultation Paper, DELWP, Melbourne, viewed 25 April 2017, <http://www.delwp.vic.gov.au/_data/assets/pdf_file/0005/351572/Consultationpaper-Victorian-renewable-energy-auction-scheme.pdf>.

Dodson, J 2014, 'Suburbia under an Energy Transition: A Socio-technical Perspective', Urban Studies, 51(7), pp.1487-1505.

Essential Services Commission 2017, Victorian Energy Efficiency Target, viewed 25 April 2017, <https://www.veet.vic.gov.au/Public/Public.aspx?id=Home>.

Gabriel, M, Rooney, M and Watson, P 2016, "'The best house possible" The everyday practices and micro-politics of achieving comfort in a low-cost home' in Cook, N Davison, A and Crabtree L (eds) Housing and Home Unbound: Intersections in Environment, Economics and Politics in Australia. Routledge Oxon. Pp. 151-166.

GreenPower 2011, What is GreenPower?, viewed 25 April 2017, <http://www.greenpower.gov.au/About-Us/What-Is-GreenPower/>.

Hall, S, Foxon, TJ and Bolton, R 2015, 'Investing in low-carbon transitions: energy finance as an adaptive market', Climate Policy. Epub ahead of print 29 October 2015. DOI: 10.1080/14693062.2015.1094731.

Hess, DJ 2013, 'Industrial fields and countervailing power: The transformation of distributed solar energy in the United States', Global Environmental Change, 23(5), pp.847-855.

Heynen, N 2016, 'Urban political ecology I: The urban century', Progress in Human Geography, 38(4), pp. 598-604

Heynen, N, Kaika, M and Swyngedouw, E (eds) 2006 In the nature of cities: urban political ecology and the politics of urban metabolism, Routledge: London. 
Hodson, M, Marvin, S and Bulkeley, H 2013, 'The intermediary organisation of low carbon cities: a comparative analysis of transitions in Greater London and Greater Manchester', Urban Studies, 50(7), pp.1403-1422.

ID Consulting 2017, Demographic Information for Local Government Areas, viewed 25 April 2017, <http://content.id.com.au/community-profiles-australia>.

Jacobs, JM 2012, 'Urban geographies I Still thinking cities relationally', Progress in Human Geography, 36(3), pp.412-422.

Jones, S 2012, 'A tale of two cities: climate change policies in Vancouver and Melbourne-barometers of cooperative federalism?', International Journal of Urban and Regional Research, 36(6), pp.1242-1267.

Latour, B 2005, Reassembling the Social: An Introduction to Actor-Network-Theory, Oxford University Press, Oxford.

Lovell, $\mathrm{H}$ and Liverman, D 2010, 'Understanding Carbon Offset Technologies', New Political Economy, 15(2), pp.255-273.

McCann, E and Ward, K 2012, 'Policy Assemblages, Mobilities and Mutations: Toward a Multidisciplinary Conversation', Political Studies Review, 10(3), pp.325-32.

McFarlane, C 2009, 'Translocal assemblages: Space, power and social movements.' Geoforum, 40(4), pp.561-7.

McGuirk, P, Bulkeley, H and Dowling, R 2014a, 'Practices, programs and projects of urban carbon governance: Perspectives form the Australian City', Geoforum, 52, pp.137-147.

McGuirk, P, Dowling, R and Bulkeley, H 2014b, 'Repositioning urban governments? Energy efficiency and Australia's changing climate and energy governance regimes', Urban Studies, 51(13), pp.2717-2734.

McGuirk, P, Dowling, R, Brennan, C and Bulkeley, H 2015, 'Urban Carbon Governance Experiments: The Role of Australian Local Governments', Geographical Research, 53(1), pp.39-52.

McGuirk, P, Bulkeley, $\mathrm{H}$ and Dowling, R 2016, 'Configuring urban carbon governance: insights from Sydney, Australia', Annals of the American Association of Geographers, 106(1), pp.145-166.

Moreland City Council 2014, Zero Carbon Evolution: Getting on track to a carbon neutral Moreland Community, Moreland City Council, Melbourne, viewed 25 April 2017, <http://www.moreland.vic.gov.au/globalassets/key-docs/policy-strategyplan/zero-carbon-evolution-strategy.pdf>. 
Moreland City Council 2015a, Corporate Carbon Reduction Plan: On track to zero carbon 2015 - 2020, Moreland City Council, Melbourne, viewed 25 April 2017, <http://www.moreland.vic.gov.au/globalassets/areas/esd/corporate-carbon-reductionplan---graphic-designed---esd---council-endorsed2.pdf>.

Moreland City Council 2015b, Moreland City Council Annual Report 2014-2015, Moreland City Council, Melbourne, viewed 25 April 2017, $<$ http://www.moreland.vic.gov.au/globalassets/areas/governance/moreland-annualreport-2014-2015-final-9-dec-15.pdf>.

Moreland City Council 2016, Moreland City Council Annual Report 2015-2016, Moreland City Council, Melbourne, viewed 25 April 2017, $<$ http://www.moreland.vic.gov.au/globalassets/areas/communications/morelandannual-report-2015-16-designed--final---web.pdf>.

Moreland City Council 2017, Energy efficiency projects, viewed 25 April 2017, <http://www.moreland.vic.gov.au/environment-bins/environment/climatechange/energy-efficiency-projects/>.

Moreland Energy Foundation 2015, Moreland Energy Foundation Annual Report 2014-15, MEFL, Melbourne, viewed 25 April 2017, <http://www.mefl.com.au/mefl2016/wp-content/uploads/2016/08/MEFL-AnnualReport-2014-15.pdf>.

Northern Alliance for Greenhouse Action 2015, Municipal Energy Profiles, viewed 25 April 2017, <http://www.naga.org.au/municipal-energy-data.html>.

Peacock Media Group 2017, How Much Do Solar Panels Cost?, viewed 5 October 2017, < https://www.solarquotes.com.au/panels/cost/>.

Pearse, R 2016, 'Moving targets: Carbon pricing, energy markets, and social movements in Australia', Environmental Politics, 25(6), pp.1079-1101.

Peck, J \& Theodore, N 2012, 'Follow the policy: a distended case approach', Environment and Planning A, 44(1), pp.21-30.

Rice, JL 2010, 'Climate, Carbon, and Territory: Greenhouse Gas Mitigation in Seattle, Washington', Annals of the Association of American Geographers, 100(4), pp.929-37.

Rice, JL 2014, 'An urban political ecology of climate change governance', Geography Compass, 8(6), pp.381-394.

Rutherford, J 2011, 'Rethinking the relational socio-technical materialities of cities and ICTs', Journal or Urban Technology, 18(1), pp.21-23.

Rutherford, J and Coutard, O 2014, 'Urban Energy Transitions: Places, Processes and Politics of Socio-technical Change', Urban Studies, 51(7), pp.1353-1377. 
Rutherford, J and Jaglin, S 2015, 'Introduction to the Special Issue - Urban Energy Governance: Local Actions, Capacities and Politics', Energy Policy, 78, pp.173-178.

Sayre, NF 2010, 'Climate change, scale, and devaluation: the challenge of our built environment', Washington and Lee Journal of Energy, Climate, and the Environment, 1(1), p.93-105.

Shearmur, R and Poirier, V 2016, 'Conceptualizing nonmarket municipal entrepreneurship: Everyday municipal innovation and the roles of metropolitan context, internal resources, and learning', Urban Affairs Review, vol. 53(4), 718-751.

Sustainable Melbourne Fund 2017, Environmental Upgrade Agreements, viewed 6 June 2017, <http://sustainablemelbournefund.com.au/services/environmentalupgrade-agreements/>.

Tweed, J 2014, 'Local Energy Collaboration: The role of local authorities in community energy', People, Place \& Policy Online, 8(3), pp.249-254.

Waitt, G, Caputi, P, Gibson, C, Farbotko, C, Head, L, Gill, N and Stanes, E 2012, 'Sustainable Household Capability: which households are doing the work of environmental sustainability', Australian Geographer, 43(1), pp.51-74).

Webb, J 2012, 'Climate Change and Society: The Chimera of Behaviour Change Technologies', Sociology, 46(1), pp.109-125.

Webb, J 2015, 'Improvising innovation in UK urban district heating: the convergence of social and environmental agendas in Aberdeen', Energy Policy, 78, pp.265-272.

Young, M 2017, Cities Affirm Their Commitment to the goals of the Paris Climate Accords, viewed 6 June 2017, <http://www.100resilientcities.org/blog/entry/citiesaffirm-their-commitment-to-goals-of-the-paris-climate-accords\#/-_/>.

Zeppel, H 2011, 'Governing carbon mitigation and climate change within local councils: A Case Study of Adelaide', South Australia. Commonwealth Journal of Local Governance, (10). 